\title{
Policies on the Vietnamese Language in Vietnam - A Historical - Social Analysis
}

\begin{abstract}
Truong Thi My Linh, ${ }^{1 *}$
IPh.D. Student, Peoples' Friendship University of Russia, 117198, Russia

"Corresponding author.Email: truonglinh93@mail.ru

ABSTRACT

The article gives an overview of the Vietnamese state's policies toward the Vietnamese language from 1945 to the present. The historical - social analysis of state policies on the Vietnamese language was conducted by analysis, synthesis, and comparison methods. The primary materials used in this article are the legal documents of the modern Vietnamese state through historical periods and research works of some Vietnamese scholars. The author established two significant tasks: Clarifying the necessity of making policies on the Vietnamese language in Vietnam and analyzing the movement and development of these policies in the legal process of Vietnam. The research results show that: (1) The development and improvement of policies on the Vietnamese language in Vietnam are significant because of these reasons: the rational and civilized behaviors of a sovereign state to its official language, the critical role of the Vietnamese language in the culture and development of Vietnamese people, the multi-ethnic country, the extensive use of Vietnamese, and new challenges put for Vietnamese language in the process of cultural exchange today; (2) Policies toward the Vietnamese language during the historical periods incessantly development and supplement, and always ensure consistency in recognizing the importance of the Vietnamese language.
\end{abstract}

Keywords: Vietnamese language, policy, law, state.

\section{INTRODUCTION}

Vietnamese language or the "the Quoc Ngu script" has had a more-than-three-century history of development attaching to the missionary activities of Western missionaries in the 16th century in Vietnam [1]. By the time the Democratic Republic of Vietnam was formed in the middle of the twentieth century, Vietnamese had a vital position unmatched in its development history, became the common script for the whole nation. In a rule-of-law state like the Democratic Republic of Vietnam, which later became the Socialist Republic of Vietnam (since 1976), the Vietnamese language has become one subject of national law and policy. The policy has understood as the choice of the state in conducting a specific issue in society. Policies are categories of content that are usually represented in the forms of decisions, plans, activities, and legal documents of the state. Research on policies toward the Vietnamese language has been the attractive matter of many scientific fields from languages, culture, history to law, politics. The context of increasing international cooperation and cultural exchange nowadays has placed the Vietnamese language in front of new challenges. A historical - social view of the policy on the Vietnamese language will contribute relevant and meaningful ideas in the development process of the national writing. The author has mobilized the methods of analysis, synthesis, and comparison as the means of conducting this study. In this process, the author placed legal documents and policies of the Vietnamese state on the timeline, corresponding to each historical context and the development of society.

\section{RESULTS}

\subsection{The Essential of the policies on the Vietnamese language in Vietnam}

Firstly, the policy towards Vietnamese language is the familiar and civilized conduct of a sovereign state towards the official language on Vietnamese territory. For such an important issue as the spoken and written language of the nation, the formulation and implementation of policies towards it are necessary. In fact, not only in Vietnam but also in any civilized country in the world, there have been regulations at different levels referring to its official language. In the Russian Constitution, Article 68 stipulated: "1. The Russian language shall be a state language on the whole territory of the Russian Federation. 2. The Republics shall have the right to establish their own state languages. In the bodies of state authority and local selfgovernment, state institutions of the Republics they shall be used together with the state language of the Russian Federation. 3. The Russian Federation shall guarantee to all of its peoples the right to preserve their native language and to create conditions for its study and development." [2] On the contrary, these regulations are considered to be the 
process of establishing a legal and compulsory basis for the entire population to use an official language.

Secondly, the important role of the language in culture and development of Vietnamese people. Script is an integral part of the culture. All cultures from the beginning to the present have associated with the handwriting element. In Vietnam, the Dong Son culture period in the first millennium BC even had "script" [3]. In the process of cultural exchange, integration, and development, Vietnamese society has passed the periods of using the Han characters, creating the Nom scripts, using the French language, and creating the Quoc Ngu script - Vietnamese language [4]. In fact, some peoples in the world undergone colonizations received the official script from the people colonized themselves. This did not happen to Vietnam. The destiny of the Vietnamese language has been associated with the factor of French colonial aggression since the 19th century. Under the French domination, Vietnamese ranked after French and was only used in literary and journalistic writing. However, when it regained its independence, the government's policy was to use Vietnamese as a universal language for the entire nation. Currently, Vietnamese is also a means to dominate the knowledge of Vietnamese people, especially learning national history and culture. 4.000 years of Vietnamese cultural traditions have preserved in Vietnamese. Vietnamese has become an essential language for Vietnamese people.

Thirdly, the policy towards the Vietnamese language is urgent in a multi-ethnic country. Vietnam has 54 ethnic groups, of which, Viet people account for $86 \%$ (also Vietnamese users) [3]. In addition to Vietnamese, ethnic minorities still use spoken and written language within their ethnic boundaries. The provisions on the Vietnamese language with the main content of affirming its position as the official language among languages existing in the Vietnam's territory are fundamental. This is related to equality in society, while the language of the majority is used as a common language and also facilitates different ethnic minorities to communicate with each other in one language. From there, the issue has linked up with the relations between official language policy and the conduct of unofficial languages. The provisions to both ensure the preservation of linguistic diversity and respect for ethnic minorities should be expressed through policies on official languages.

Fourthly, the Vietnamese language has not limited to national scopes. This has been an indispensable history of the migration process of Vietnamese people that took place for centuries due to wars and divisions in Vietnam. That tangible migration leads to the invisible migration of the Vietnamese language. Although that migration is hidden, its products are visible in the overseas Vietnamese community. The Vietnamese language has become an invisible link between overseas Vietnamese and ethnic, origin factors. Therefore, in a specific aspect, the policies on the Vietnamese language needs to pay attention to its borderlessness, i.e., to overseas Vietnamese people.

Fifthly, the process of cultural exchange today has put the Vietnamese language ahead of modern challenges. These challenges have come from preserving the Vietnamese language and using foreign languages. Correct regulations on the use of the Vietnamese language will be the state's indispensable conduct towards the preservation and even export of Vietnamese culture. Many misleading phenomena in using the Vietnamese language, as well as the increasing necessity of using world-wide languages, will require appropriate policies on the Vietnamese language. Without sufficient interest in Vietnamese, the process of cultural exchange, in particular, the language exchange, will lead to negative consequences and the object of damage will be the Vietnamese language.

\subsection{Policies on the Vietnamese State toward the Vietnamese language through Historical Periods}

- Changes in the way of defining the position of the Vietnamese language in Vietnamese policies and laws during historical periods

+ From 1945 to 1969: The Vietnamese language was not directly mentioned as the official language of the country but as "the Quoc Ngu script". Article 18 of the first Constitution of Vietnam in 1946 states: "The candidate must have the right to vote, must be at least 21 years old, and must read and write the Quoc Ngu script." [5]

+ From 1969 to 1998: Vietnamese was defined as "the common language". During this period, the Vietnamese Constitution 1980 did not address Vietnamese issues directly. However, in practice, Vietnamese was used as a means of communication in many fields of administration, politics, culture, and society. However, the phrase "the common language" was used in the Government Council's Decision No.153 of August 20, 1969, with the regulation "All ethnic groups living in the territory of Vietnam need to learn and using the common language of the whole country." [6] By 1980, the Government Council's Decision No. 53 of February 22, 1980 also recorded the "common language" status of the Vietnamese language: "the common language is the language of all ethnic communities in Vietnam."'[7]

+ From 1998 to 2013: The Vietnamese language was stated by law as the "official language". Entering this stage, the field of education took on a more critical responsibility for Vietnamese and the fact that the Law on Primary Education dated December 10, 1998, stated: "Vietnamese is the official language used in schools." [8] From here, Vietnamese has had a clear and essential position in the language system with a specific legal basis. The Law on Education 2005, in Article 7, continued to stipulate "Vietnamese is the official language used in schools and other educational institutions." [9]

+ From 2013 to the present: Vietnamese has been recognized by law as both an "official language" and a "national language". From the 2013 Constitution, the interest of legislators for Vietnamese has been deeply reflected in Article 5 with the acknowledgment "The national language is Vietnamese. Ethnic groups have the 
right to use their spoken and written language, preserve their national identity, promote their fine customs, practices, traditions, and culture." [10] At the same time, Article 11, Law on Education in 2019 also continued to affirm "Vietnamese is the official language used in educational institutions." [11]

The step-by-step process of establishing the position as the national language of Vietnamese shows at least the following issues: (1) Deeper interest in Vietnamese, (2) Irreplaceable position of the Vietnamese language in Vietnamese society, (3) Consistent policy on respect and development of the Vietnamese language in the process of modern national history.

- The impact of policies on the Vietnamese language in the history of the Vietnamese nation

+ The first period: This period lasted from the birth of the Democratic Republic of Vietnam and in the two wars of resistance against French colonialism and American imperialism of the Vietnamese nation (from 1945 to 1975). Impacts with state policies on the Vietnamese language are mainly expressed through the following contents:

Firstly, calling for learning Vietnamese. Decree No.19 of the President of the Provisional Government of the Democratic Republic of Vietnam on September 8, 1945, stipulated that "Learning the Quoc Ngu script is compulsory and free of charge for everyone." [12]. This policy was further developed until 1969 with Prime Ministerial Decision No. 153 of August 20, 1969, stipulating: "All ethnic groups living in the territory of Vietnam need to learn and use the common language. The State should try its best to help people of ethnic minorities to learn quickly common language."'[6]

Secondly, formulating forms and measures for learning Vietnamese in the condition that the country was still poor and backward. Decree No.19 of the President of the Provisional Government ordered: "Within one year, all Vietnamese people over the age of eight must be able to read and write the Quoc Ngu script. Past that time limit, a Vietnamese over 8 years old who can not read and write the Quoc Ngu script will be fined." [12] The Presidential Decree No.20 of the Provisional Government on September 8, 1945, ordered: "In the whole of Vietnam, farmers and workers will have popular evening classes. Within six months, every village and urban must have at least a class that teaches at least 30 people." [13]

Thirdly, promoting the development of the Vietnamese language and maintaining links with the overseas Vietnamese community. This task was assigned to universities of language at that time with the content of teaching Vietnamese to foreigners. At the same time, the Vietnam Television Station also established Vietnamese teaching programs for Vietnamese people far away from the Fatherland.

Fourthly, preserving the purity of the Vietnamese language. In a speech at the 1st Conference on Preserving the Vietnamese Language in 1966, the late Prime Minister Pham Van Dong affirmed that our Vietnamese is very rich and beautiful. The conference concluded three steps to preserve the purity of the Vietnamese language: Preserving and developing the capital of our language; speaking and writing according to the rules of our language; preserving the identity, quintessence, style of our language in all forms of literature (art, politics, science, technology). [14] + The second period: After the liberation of South Vietnam, the unification of the country from 1975 to the present. When the country's history entered the period of peace and independence, the Vietnamese language has been deeply studied its role and meaning to the nation. At this time, state policies focused on the following:

Firstly, recognizing the rights and responsibilities of using Vietnamese. Decision No. 53 of the Government Council on February 22, 1980 noted: "The common language is the language of the Vietnamese ethnic community. It is an indispensable means for exchanging between localities and peoples throughout the country, enabling localities and peoples to develop equally in the fields of economy, culture, science and technology, strengthening the great unity bloc of the entire people and exercising the rights of national equality. Therefore, all Vietnamese people have the obligations and rights to study and use the common language." [7]

Secondly, standardizing the Vietnamese language. After the country's reunification, in the late 1979 and early 1980 s, the responsibility for standardizing the Vietnamese language was expected in the conferences between the Vietnam Social Science Committee and the Institute of Educational Science - Ministry of Education. In 1984, the Ministry of Education and Training issued a vital legal document to promulgate the regulation on Vietnamese spelling and Vietnamese terminology applied to textbooks, newspapers, and papers of the education sector. [15]

Thirdly, the issue of using Vietnamese and foreign languages. Government Decree No. 194 of December 31, 1994 , on advertising activities on the Vietnamese territory, stated the voices and words used in advertisements must be Vietnamese voices and scripts, except for cases prescribed by law. In cases of using both voices and words of foreign languages, must write Vietnamese letters first, above, and in a larger size than foreign words, must read Vietnamese first, foreign languages later [16].

From 2013, Vietnamese has entered the period of protection and concern of the entire nation due to the status as a "national language". Many "Vietnamese improvement movements" and "improvements in Vietnamese language teaching" have brought about lively debates in society. Typically, the modified Vietnamese script of Professor Bui Hien [17] and the Vietnamese book series of the advanced education program of the editor Professor Ho Ngoc Dai [18]. Negative and positive aspects that coexist in these debates are inevitable; however, from a social perspective, people's high interest in the Vietnamese language through these debates is undeniable. 
[4] C. B. Huynh, Vietnamese cultural origins and

\section{CONCLUSION}

Policies on the Vietnamese language in Vietnam have already existed in the modern Vietnamese state. Both practical and theoretical reasons point out the need to develop and complete these dealing with the following fundamental aims: The policies toward the Vietnamese language are the reasonable and civilized conduct of a sovereign state over its official language; the critical role of the Vietnamese language for Vietnamese culture and human development; Vietnam is a multi-ethnic country; the scope of using Vietnamese crosses Vietnamese national borders; the process of cultural exchange today puts Vietnamese in front of new challenges.

Policies of the Vietnamese state toward Vietnamese through periods are both consistent and complementary. Up to now, Vietnamese is officially recognized by law as "official language", "national language". That process has witnessed substantial impacts of the state on the Vietnamese language despite the country's difficult or favorable circumstances. The content of these impacts manifests itself at various levels: calling for learning Vietnamese, establishing forms and measures for learning Vietnamese, promoting Vietnamese development and maintaining links with the overseas Vietnamese community, preserving the purity of the Vietnamese language, recognizing the rights and responsibilities of using the Vietnamese language, standardizing and improving the Vietnamese language.

In the flow of social development, the State needs to continue to concretize policies on the Vietnamese language, consider decisions related to current issues such as improving Vietnamese. All the right policies are always based on: the solid theoretical and practical bases, the derivation from the aspirations of the people, the cultural traditions of the nation, and the requirements of development in the new era.

\section{REFERENCES}

[1] Q. H. Do, V. N. Tran, Modernity and the transformation of Vietnamese culture in modern times, Social Sciences Publishing House, Hanoi, 2011, p. 171.

[2] The Constitution of the Russian Federation, the Constitutional Assembly of the Russian Federation, 1993.

[3] History Department - Institute of Social Sciences and Humanities - Ha Noi National University, Vietnam in world history, Hanoi National University Press, Hanoi, 2015, p. 29. identity, Thuan Hoa Publishing House, Ho Chi Minh City, 2018.

[5] The constitution of Vietnam, The National Assembly of Vietnam, 1946.

[6] The Government Council's Decision No.153 on constructing, improving and using scripts of the ethnic minority, The Government Council of Vietnam, 1969.

[7] The Government Council's Decision No. 53 on guidelines for the writing of ethnic minorities, The Government Council of Vietnam, 1980.

[8] Law on Primary Education, The National Assembly of Vietnam, 1998.

[9] Law on Education, The National Assembly of Vietnam, 2005.

[10] The constitution of Vietnam, The National Assembly of Vietnam, 2013.

[11] Law on Education, The National Assembly of Vietnam, 2019.

[12] The Presidential Decree No.19 on establishing an affordable class for farmers and workers, The President of the Provisional Government of Vietnam, 1945.

[13] The Presidential Decree No.20 on education, The President of the Provisional Government of Vietnam, 1945.

[14] V. L. Pham, The Vietnamese language exists, Vietnamese people live, 2019. Retrieved from https://news.zing.vn/tieng-viet-con-nguoi-viet-conpost914554.html

[15] The Ministerial Decision No.240 on Vietnamese spelling and Vietnamese terminology applied to textbooks, newspapers, and papers of the education sector, The Minister of Education and Training of Vietnam, 1984.

[16] Government Decree No. 194 on advertising activities on the Vietnamese territory, The Government of Vietnam, 1994.

[17] Information on https://vnexpress.net/topic/de-xuatcai-tien-chu-viet-tieng-viet-22616

[18] Information on https://vnexpress.net/topic/sachgiao-khoa-cua-gs-ho-ngoc-dai-gay-tranh-cai-23280 